\title{
Numerical Estimation of Noise Emitted by Industrial Tube Burner
}

\author{
Syuichi AOKI*4, Yasutaka KUME and Kazuhiko KUDO \\ ${ }^{*}$ Fundamental Research Department, Toho Gas Co., Ltd. \\ 507-2 Shinpo-machi, Tokai-shi, Aichi, 476-8501 Japan
}

\begin{abstract}
To estimate the noise emitted by a industrial tube burners (immersion tube burner and radiant tube burner), simulated and experimental analyses are carried out. Firstly, combustion noise is measured and the overall characteristic of noise is examined. Secondly, one-dimensional noise analysis programmed with a transfer matrix method is used. A lot of efforts have been made to analyze the noise from home use combustion device considering the temperature distribution inside the tube. In this study, the distribution of heat generation rate is taken into account to obtain sufficient accuracy for the noise at the exhaust tube outlet, in addition to the conventional temperature distribution. The distribution of heat generation rate is numerically analyzed considering the heat transfer at the inner and outer surface and the radiation at the outer surface of combustion tube. As a result, the theoretical results show relatively good agreement with the experimental results and the analytical method employed in this study has been confirmed to be practical for noise analysis of industrial tube burners.
\end{abstract}

Key Words: Noise. Combustion Oscillation, Burner, Transfer Matrix, Heat Generation Ratio

\section{1. 緒言}

管内燃焼器からはしばしば共鳴音による騒音事例が 報告され，問題となる場合がある。これは，機器類の コンパクト化, 高負荷化への流れの中で, 燃焼に伴う 騒音, ひいては管内燃燒器の騒音が増加することに起 因する。管内燃焼器の中でも比較的小形の家庭用燃焼 器や大形の発電ボイラ等においてはこれまでにも数多 くの研究が報告されているが, 中規模の工業用燃焼器 については，あまり騒音研究開発事例がない.

しかし，丁業等における作業環境の改善への動きか ら, 工業用燃焼器の騒音低減のニーズが高くなってき ている. 従来では, 送風機等のバーナ周辺機器がかな りの騒音を発生していたが, 最近ではこれらから発生 する騒音の低隇が図られたこともあり，管内燃焼器か ら発生する騒音が問題として挙がり，対策が求められ ることが多い。しかしながら，現状では試行錯誤的に

\footnotetext{
* 原稿受付 2001 年 1 月 29 日.

*1 正員. 東邦ガス(株) 基盤技術研究部(兆476-8501 東海沛新 (镡町 $507-2)$.

*2. 東邦ガ久(株) 基盤技術研究部.

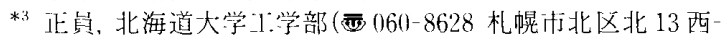
8).

E-mail : saoki a tohogas.co.jp
}

騒音低減の試みがなされる場合がほとんどであり低減 対策手法として確立されたものはない，都市ガスを燃 料とする実用的な管内燃焼機器としては, 浸管バーナ (ITB)，ラジアントチューブバーナ(RTB)があり, 間 接加熱炉で利用されるものである. 各バーナの形態は 多様であるため，はん用的に利用できる基礎技術の確 立が重要である。さらに燃焼器の騒音が問題となる場 合，解析を行うために長期間を要するものでは現実的 でなく, 機器の開発者の抱える問題, 現場で発生した 課題の解決に即応できるものであることが要求され る.

これまでの研究の中で燃焼器の騒音源となる管内に おける火炎加ら発生する騒音の大きさについては, Bragg らの報告(1)がある。また周波数特性について は, Shivashankara ${ }^{(2)}$ ，小竹(3) らにより燃焼形態に特 有の傾向について報告されている。これらを適用する ことにより入口音の予測が可能となり, 燃焼機器内を 伝ぱする騒音の伝達関数を予測する技術を確立すれ ば，出口音の予測が可能になる。

本報では, 主たる管内燃焼器であるITBとRTB から発生する騒音の予測技術の確立を目的とする。 


\section{2. おもな記号}

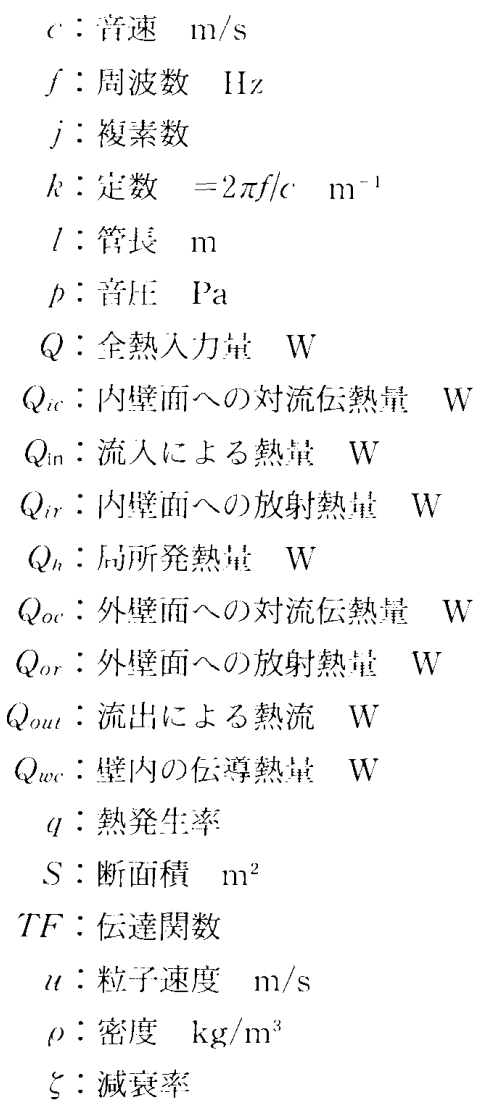

\section{3. 実験装置, 測定装置}

$3 \cdot 1$ 浸管バーナ(ITB）ＩTB の断酒闵を四 1 に 亦す。在側の太い部分が燃燒筒で，左側の細い部分が 漁管部分である。また燃焼筒は、䕕管との接合側が师

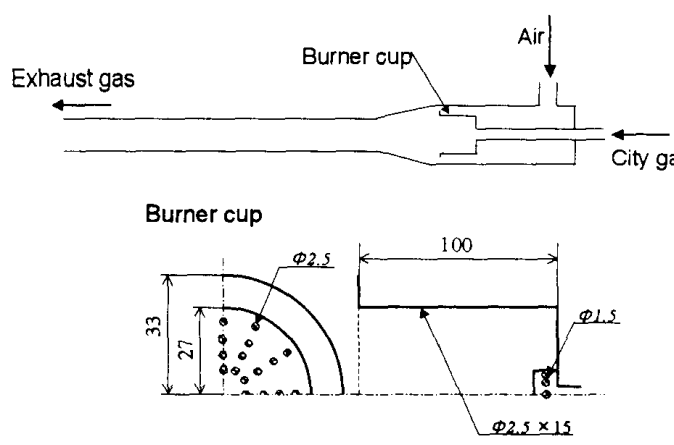

Fig. 1 Scheme of experimental apparatus

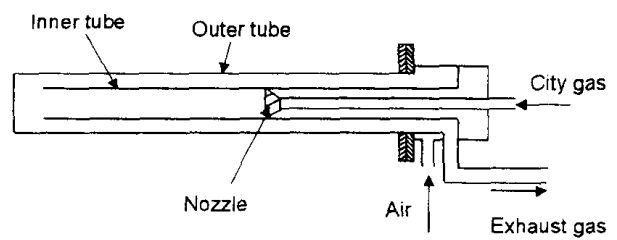

Fig. 2 Scheme of experimental apparatus
寸い吉状になっている。燃焼筒部分は内待 $\phi 70.6 \mathrm{~mm}$

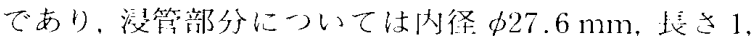

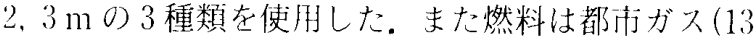
$\mathrm{A}$ : 組成比 $\mathrm{CH}_{4}: \mathrm{C}_{2} \mathrm{H}_{6}: \mathrm{C}_{3} \mathrm{H}_{8}: \mathrm{C}_{4} \mathrm{H}_{10}=88: 6: 4:$ 2) とし, 連転条件沙熱入力 $12.8 \mathrm{~kW}(13 \mathrm{~A}$ 流青 1.0

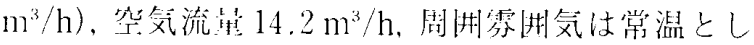
た。

$3 \cdot 2$ ラジアントチューブバーナ $($ RTH $) \quad R T B$ にはきまざまな几径のものがあるが，本研究では㳎く 利用きれている“3 inタイプ”のものを物いた。断诵

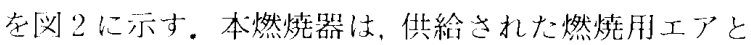
都泫ガスがノズルから噴出し，内管内にて長炎を形成 するものである。燃焼ガス收左端で折り这し、内管と 外管のすきまを通り，在端上り排気される。内管内畦 は $\phi 65 \mathrm{~mm}$, 外栙 $\phi 75 \mathrm{~mm}$, 内管镜さ $1.25 \mathrm{~m}$ である。 一厅，外管内径は $\phi 104 \mathrm{~mm}$, 外管长さ $1.3 \mathrm{~m}$ である。 燃料は都沛ガス $(13 \mathrm{~A})$ とし，筀格運転条件は熱入力 $15.6 \mathrm{~kW}\left(13 \mathrm{~A}\right.$ 流地は $\left.1.2 \mathrm{~m}^{3} / \mathrm{h}\right)$, 空気流星は 17.1

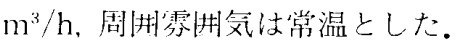

$3 \cdot 3$ 測定方法 ITB, RTBO内管内扩よび

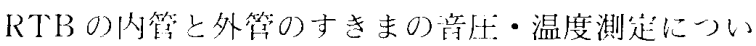
ては、管に $100 \mathrm{~mm}$ 間隔でサンプリング孔を設け、管

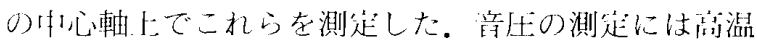
耐熱マイクロフォン形式 4182(B＆Ｋ＼cjkstart社製）を用いた。 ガス温度は， $\mathrm{R}$ 熱電対(線径 $\phi 0.2 \mathrm{~mm}$ )で管内昍心を 計測してふく射補正した。ガス温度の位置による变化 の大きいバーナノズル下流付近においては，测足点を 堌やして测足した。喜化の测筀システムを图3に示 㱑.

燃狫器からの騒音は、排ガス出「端面から軸方问に $10 \mathrm{~mm}$, 半径方向 $150 \mathrm{~mm}$ の地点に扔いて指问特性が $I \cos \theta$ のコンデンサマイクロフォン形式 3520 (B \& $\mathrm{K}$ 社製)を用い，無音響室内にて测垐した。マイクロ フォンの設置位置で燃焼排ガス流による風生を直接受 けることはないため，風切り音による影響はない。ま た測走した音任は排ガス出口から兰次元的に伝ぱする ものを测定していることを考虑して測定音作から排ガ

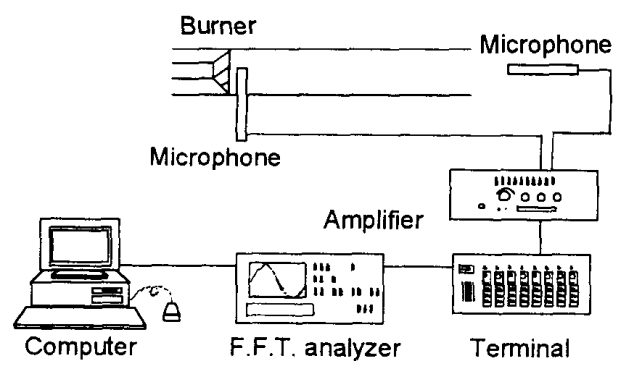

Fig. 3 Measurement system 
Table 1 Specification of anechoic room

\begin{tabular}{|c|c|}
\hline Dimension & W4.5 $\times \mathrm{D} 4.5 \times \mathrm{H} 3.5 \mathrm{~m}$ \\
\hline Background noise & under $20 \mathrm{~dB}(\mathrm{~A})$ \\
\hline Exhaust equipment & $50 \mathrm{~m}^{3} / \mathrm{min}$ \\
\hline
\end{tabular}

ス出门における音圧を算出した。実験に使用した無音 響室の性能表を表 1 に示す。

\section{4. 理 論 解 析}

4 ・1 伝達マトリックス四端子定数を用いた伝 達マトリックス法(4)により音響解析を行った。入「 の音圧, 粒子速度を $p_{1}, u_{1}$ 同様に出口について, $p_{2}$, u2 とすると両者の関係は次のように表すことができ る.

伝達マトリックス計算の際，音速を $300 \mathrm{~m} / \mathrm{s}$ とした とき，解析周波数上限を $2 \mathrm{kHz}$ とするため，音響解析 の各要素の幅は $25 \mathrm{~mm}$ 以下となるように設筀した。 な打燃料は完全燃焼するものとし，燃焼ガスの諸物性 (比熱, 密度, 熱伝導率, 粘度)の温度依存データにつ いては「CHEMKIN J(5)を引用した。

$$
\begin{aligned}
{\left[\begin{array}{l}
p_{2} \\
u_{2}
\end{array}\right]=\left[\begin{array}{c}
\cos k l+j \frac{\zeta}{2} \sin k l \\
\frac{S}{4 \rho c} \zeta \sin ^{2} k l+j \frac{S}{\rho c} \sin k l \\
\frac{\rho c}{S} \zeta+j \frac{\rho c}{S} \sin k l \\
\cos k l+j \frac{\zeta}{2} \sin k l
\end{array}\right]\left[\begin{array}{l}
p_{1} \\
u_{1}
\end{array}\right] }
\end{aligned}
$$

$4 \cdot 2$ 伝熱計算 燃焼器内管内に打ける火炎は日 視では舆炎を形成しており，燃焼に伴う発熱が軸方向 に分布しているものと思われる。そこで，内管内ガス 温度と内管外壁面の温度を軸力向分布として整理した 測定データから式（2）により管壁を通過する熱电 $Q_{w}$ を求め, 式(3)から軸方向に小分割した内管内の各空 間における熱発生率 $q$ を算出する。この軸方向の熱 発生率分布の算出を行ううえで，内管内を通過する燃 焼ガスを軸方向に分割した場合, 各空間に扔ける熱バ ランスから次式を得る。な抄算出の際, 各空間におけ る管內ガス温度は各空間の中心軸上の温度とした。

$$
\begin{aligned}
& Q_{i c}+Q_{i r}=Q_{w c}=Q_{o c}+Q_{o r} \\
& Q_{h}=Q_{o u t}+Q_{i n}+Q_{i c}=q \cdot Q
\end{aligned}
$$

$4 \cdot 3$ 音響解析管内の騒音解析を行うために, 伝達マトリックス法を用いた騷音解析プログラムによ り，管内の騒音発生率分布を考慮して伝達関数を算出 する。この管内の騷音発生率分布の導出方法について

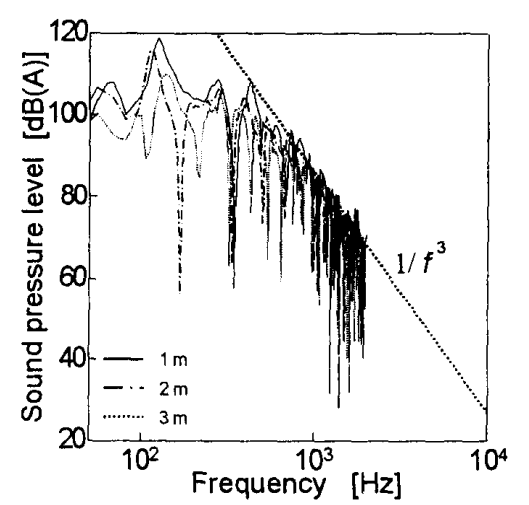

Fig. 4 Sound pressure level at inlet (ITB)

は以下゙のと㧍りである。

小竹(6)によると，燃焼騒音の音任の変動は燃焼によ

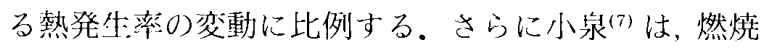
に伴う音王の変動と熱発生率との閒に比例関係

$$
\frac{\partial}{\partial t}\left[\begin{array}{cc}
1 & \partial p^{\prime} \\
c^{2} & \partial t
\end{array}\right]-\nabla^{2} p=\frac{\partial}{\partial t}\left[\frac{q}{c_{p} T}\right]^{\prime}
$$

が成り立つ仮定のもとに，音王の変動は熱発生率に比 例するとする式 (4)を導出した。このとき，管を軸方 仙に小分割したそれぞれの空間に拈いて䮎音が発生: し，各空間の振動位相が间一であると仮走した埸合， 管以軸方向の騒音発生率分有 $[q(x) p l(f)$ に比例 $]$ と出 门に打ける騒䆨 $p_{2}$ には以下゙の関係がある。

$$
p_{2}(f)=\sum_{x=1}^{l} T F_{x}(f) p_{x}(f)=\sum_{x=1}^{l} T F_{x}(f) q(x) p l(f)
$$

式(5)0)右項についてはまず，管内 $l=x$ 地点におけ る伝達関数 $p_{2} / p_{x}=T F(f) x$ は式 $(1)$ から求めるがこ のときバーナノズル端面! $(x=0)$ における境界条件が 開端の場合 $p_{1}=0$ とし, 閉端の場合 $u_{2}=0$ とする. 次 にpl $(f)$ は管内0熱発生摔の最も大きい地点に扔ける 騒音値をその地点の䦌所熱発生率で除したものであ る。これらと熱発生率が最も大きい地点での音生 と熱発生率分布 $q(x)$ の测定値と算出した伝達関数を 脚て，出口音任 $p_{2}$ を算出することができる。

\section{5. 実験および解析結果}

$5 \cdot 1$ 騒音源の周波数特性 ITB O管佥さ，1，2， $3 \mathrm{~m}$ の 3 条件について管内騒音スペクトルの測起結果

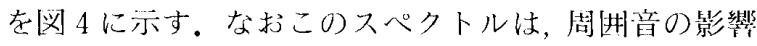
を少なくするため熱発生率の最も大きい地点に扔い て, 奌温用マイクロフォンの音庄测定用管をバーナ管 内に㨂入し測定した。图 4 より，浸管堎によらず騒音 レベルはほぼ闹一であること，ならびに周波数減衰傾 向はほぼ $1 / f^{3}$ であることがわかる。熱発告率の最も 


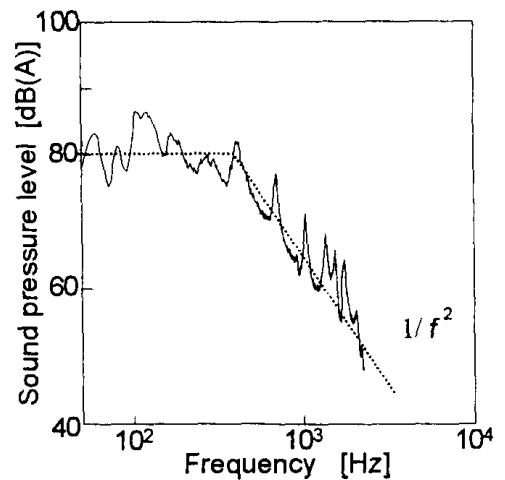

Fig. 5 Sound pressure level at inlet (RTB)

大きい部分に扝ける騒音解析が浸管堎に低存しないこ とから，以降の望響解析は浸管長を $1 \mathrm{~m}$ に湖定して行 った。

一方，四 5 はRTBの管内音压を同様に测䇥した結 果である。周波数減主特性は測定結果からほほ $1 / f^{2}$ であった。熱発生率最大位置での $500 \mathrm{H} z$ 以上の周波 数带域に㧈ける昖散火炎の隇衰特性としてはこ机まで 0)研究で, Shivashankara ら ${ }^{(1)}$ による $1 / f^{2.5}$ や小竹 ${ }^{(3)}$ による $1 / f^{2.3}$ などが報告されており，管内燃烧騷音に ついても，図4，5上りほぼ同様の傾何在示しているよ うすが稀る。

$5 \cdot 2$ 浸管バーナ(ITB）伝達関数を算出するた 如必要な管内の温度分布とこ机をもとに式(2)。 （3）を朋いて算出した管内における熱発生摔分布在汹 6 に示寸。横軸は燃狫筒端䣶を起点に排ガス出11方向 への位置である。これより，浸管内に㧈ける熱発生流

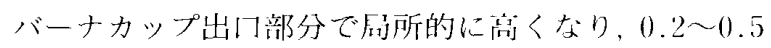
$\mathrm{m}$ 付近にほとんど集中しているようすがおかる。

次に伝達関数を算出する。伝達関数算出のための人 门側の境界位置はバーナノズル端とし，境界条件は成 所湆圷分布の测定結果から開端条件 $p=0$ とした。

また，バーナノズル端面までが音響解析の範进とし たのは、バーナノズルの部分に扔いて、本研究で音響 解析を行った領域とその上流部分に位睤する供給系と

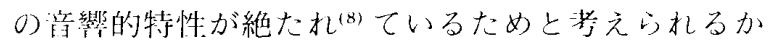
らである。

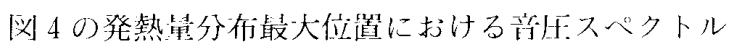
0)測足結果から求女た $b l(f)$ と伝達関数を式 $(5)$ に代 人して出りに扮ける騒音を算出した結果在图てに示 才。

これより，騒音解析結果の騷音値は，共振䧓波数以 外については実験储と比較的一致するも0)，，南周波 数領域，ならびに共振周波数の先鋭部分では䒠駼值上 り大きくなった。一方，共振周波数については、ほほ

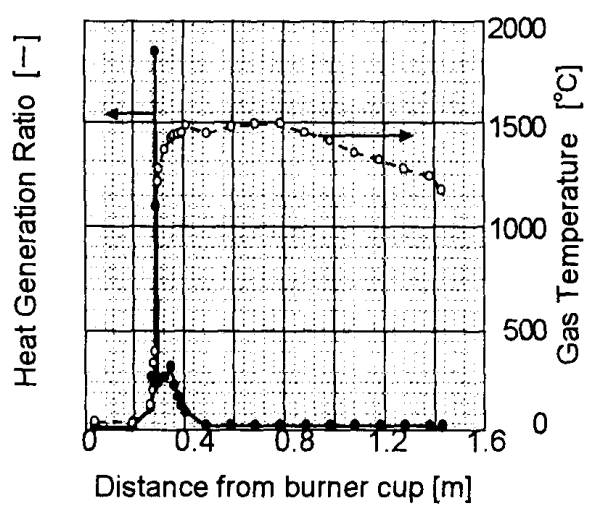

Fig. 6 Profile of gas temperature, $Q_{n}$

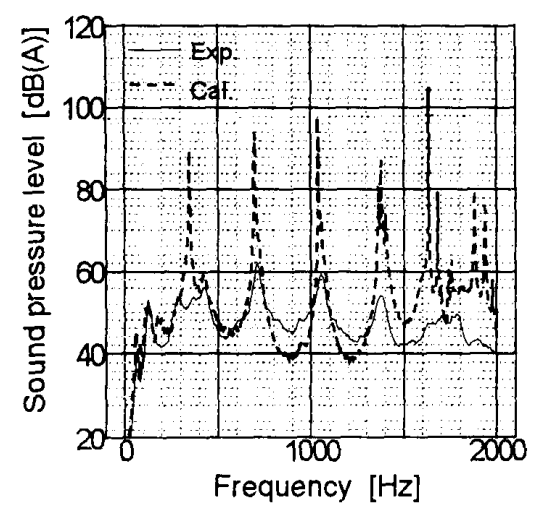

Fig. 7 Calculated S. P. L. (ITB)

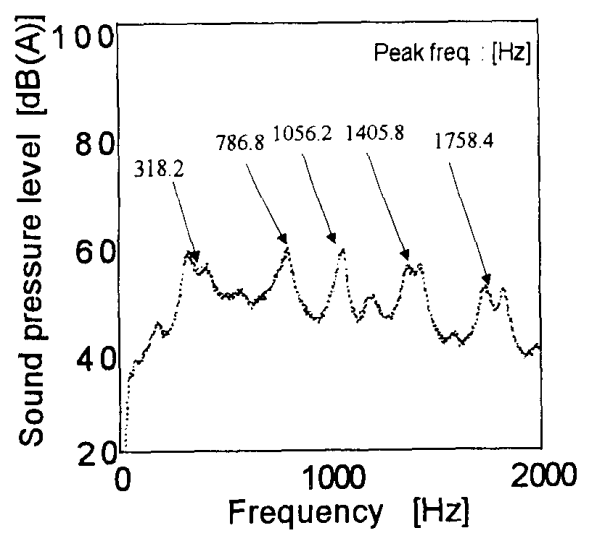

Fig. 8 sound pressure level at outlet (exp.)

实験俌と一致し，共振周波数の精度䛊差について蛙

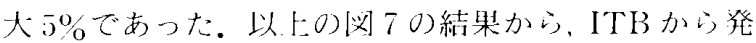

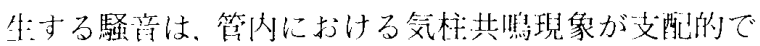
あることが確認された。

$5 \cdot 3$ ラジアントチューブバーナ (RTB) RTH

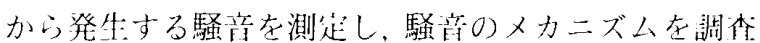
した、はじめに出り付近において测走した騒部レベル

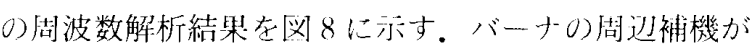

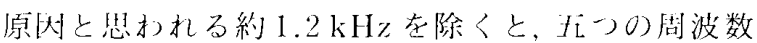




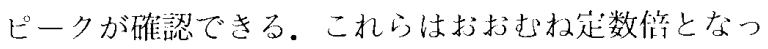
ていることから，RTB内で気柱共暗が発生ししている と将えられる。発生源圭調査するためピーク周波数の) うち，低周波側から318.2,786.8,1056.2 Hz(それぞ れ $n=1,2,3$ とする)0３間波数に注日儿, 内管軸力

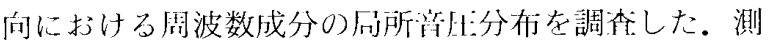

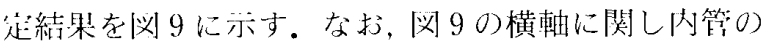

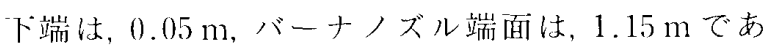
る.

内管下端ならびにバーナノズル端における后所音庄 は、いずれの䦌波数に打いても高いことがわかる。ま

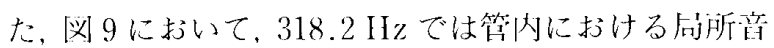
比が極小となる地点が 1 箇得である0に刘し，786.8 I $z$ では2 箈所, $1056.2 \mathrm{~Hz}$ では3箈所となってい る.一方，四 8 に示扵ピーク以外の周波数領域や，以 管と外管の寸きまに扔けるピーク周波数に扔ける可所 等忙分布を調査したが，このような特徵的な現象は確 認できなかった。以上の結果から，内管内に执いては， 気柱共㖵現象が生じていると考えられる。内管內0后 所羙压分布のようすから，内管の雨端を閉端条件とし た坋命の燃焼器か以発生:する騒音を式(5)を用いて算 出することとし，测笔結果と比較することとした。

ここで, 四90と扔り内管の両端に打ける音压が高 くなり，閉端条件となった原因を考察する。まず内管

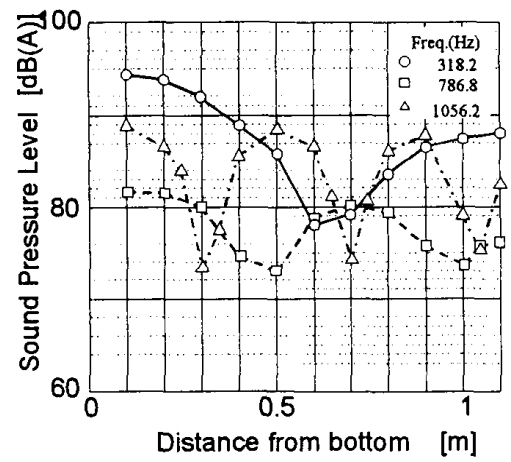

Fig. 9 Local S. P. L. in inner tube

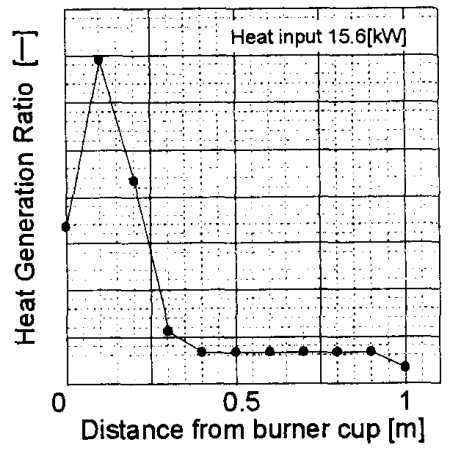

Fig. 10 Profile of gas temperature, $Q_{n}$

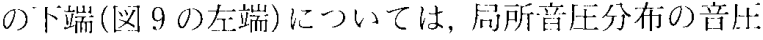
極大の位型から外管内等面が走在波の閉端の位置にな っているものと考えられる。一方，内管上端に抏いて

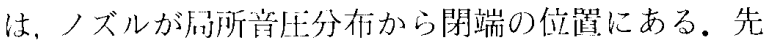
のITBではノズルの境界条件は開端であった。ここ で们者のノズルの形状を比較すると，RTBはノズル の流人门が小さいため，閉端の特性を示したものと教 えら扎る。品所音压分布の测起結果からRTBより発 生:する燃焼騒音は，内管の気柱共鳴現象が原因である ことがわかった。また，内管以降の内管と外管のすき ま等のバー十構造は, 発生する気柱共鳴のピーク周波 数を決䇥する主たる要团となっていない。

洣 10 は，測定した温度デー夕をもとに式(2)，（3） か以燃烧器内管内の発熱鲁分布を算出した結果を示し たものである。ITBでは，バーナカップ内で約 9 割の

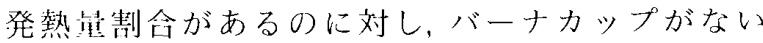
RTBでは,ノズルから下流 $0.2 \mathrm{~m}$ までの間で約 7 割 の燃料が然焼している，また，わずかな値ではあるが 発熱量が内管内の公域に分布しているようすも確認で きる。

汹 5 の燃燒器内の熱発生率最大位置での音仕 $p_{1}(f)$, 㣼 100 ) 発熱量分布 $q(x)$, 内管形状と温度分布を代入 し算出した式（1）の伝達関数 $T F$ を式(5)に代入し てバーナからの出口音 $D_{2}$ を算出した。測定結果との 比較を図 11 に示寸。ピーク周波数に着目すると, $n=$ $20786.8 \mathrm{~Hz}$ では, 実験と解析結果に約 $50 \mathrm{~Hz}$ (約 $6 \%$ )差が生じているが, その他の $n=1,3,4,5 に$ 扔いては比較的よく一致している. 以上の図 9,11 の 結果から, RTBから発生する騒音は, 内管内に拈け る気柱共鳴現象が支配的であることが確認された。

戍 11 の解析結果では, ピーク周波数は測定結果と ほぼ一致するものの, 音压レベルについては大きな違 いが生じて扔り予测精度が不汾である。そこで，出 门音の算出において燃焼騒音が音源から騒音測定点に 到達するまでに減衰する音比エネルギ一を考慮するた

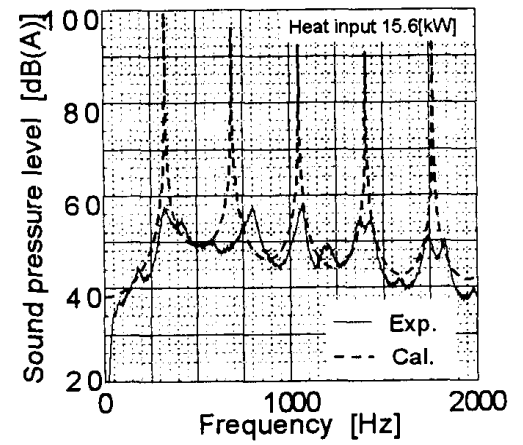

Fig. 11 Calculated S. P. L. (RTB) 


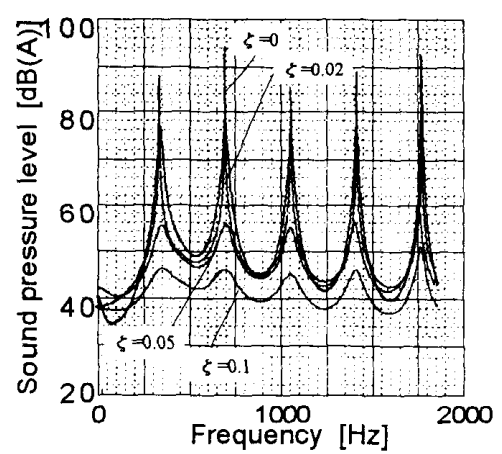

Fig. 12 Calculated S. P. L. (RTB)

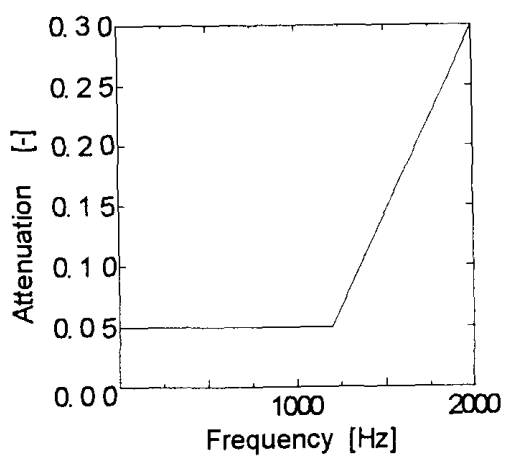

Fig. 13 Attenuation of Sound Pressure level

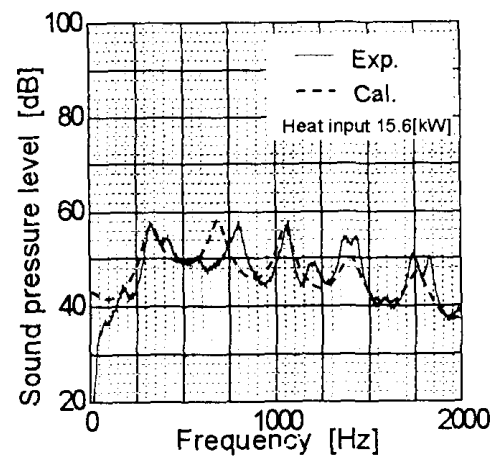

Fig. 14 Calculated S. P'. L. with Decrement

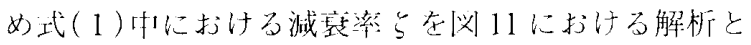
测定結果から算足与ることとした。威 12 は，RTBか

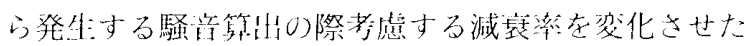

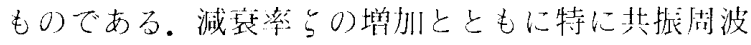
数付近における驧音值の減少傾问が落しい。

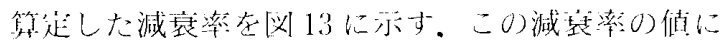
ついては、これまでに0.01〜0.(1)2(4)などが報告き机

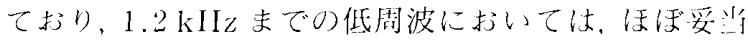
な健である。しかし1.2 kHz以上では一次䦥数的に 減衰率が上梨する結果となった。

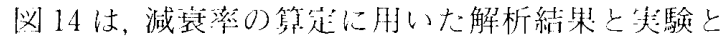

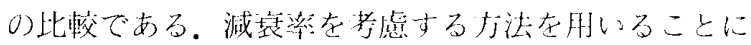
より、音灰法ベルの差は $60 \mathrm{~dB}(\mathrm{~A})$ 以上から $4 \mathrm{~dB}(\mathrm{~A})$
程度と小さくおることができる。

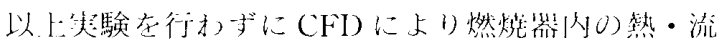

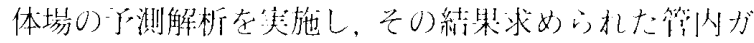

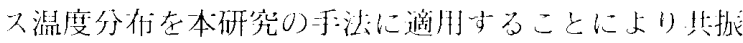
䦌波数については求めることが川能であることが小さ

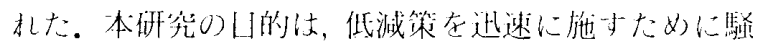

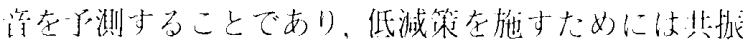

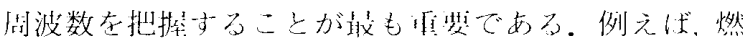

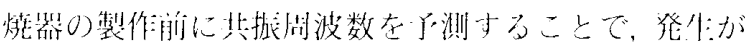

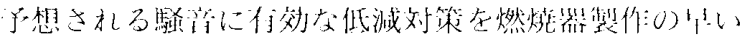

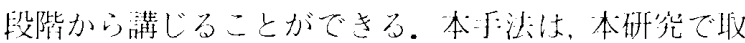

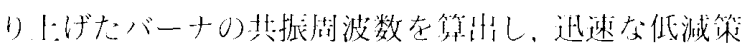
を施すツールとして們である。

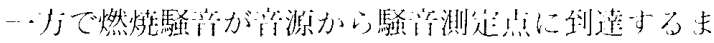

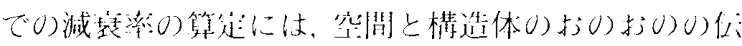

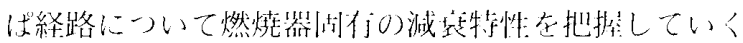

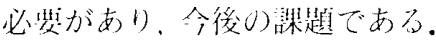

\section{6. 結 言}

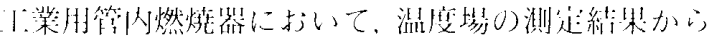

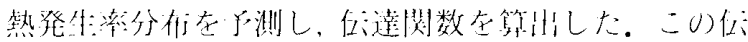

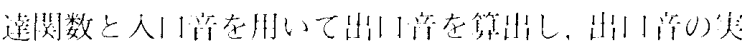

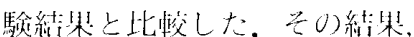

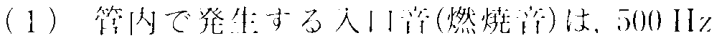

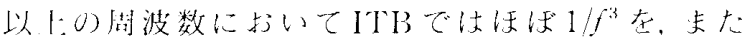

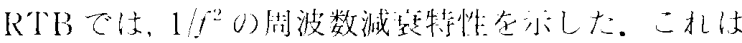

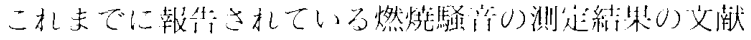

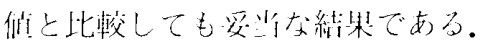

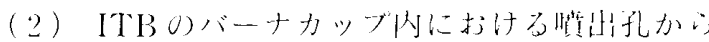

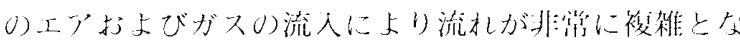

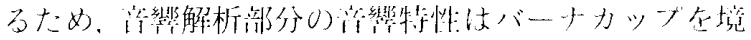

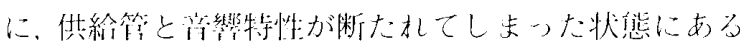

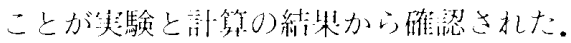

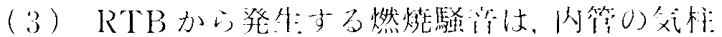

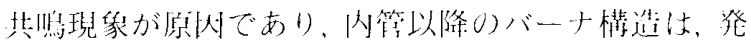

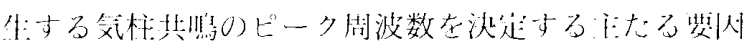
となっていない.

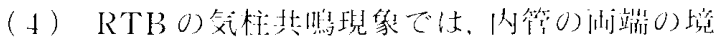
界条件が淤端となっていることが归らかとなった。卜

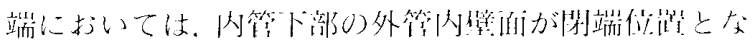

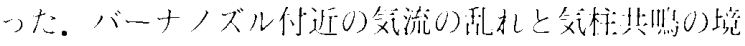

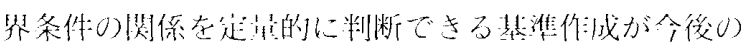
䏫題である。

（5）本手法により，ITP，RTBO）其报街波数が

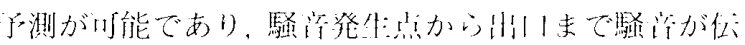

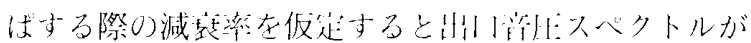


测笔优とほぼー一致する。

\section{文献}

(1) Bragg, S., J. Inst. Futl, 36 (1963), 12.

(2) Shivashankara, 保加3行, Actu Astroment. (1974), 985 992

(3) 小竹非, 械渝, $30216, B(1964), 9951001$.

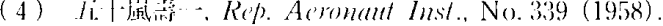

(5) Kee. R. J., 任か 4 名. Sandia R(p.. SAND $898009 \mathrm{~B}$ (1991).

(6) 小竹進, 胡: ガス, 16 (1979), 499506.

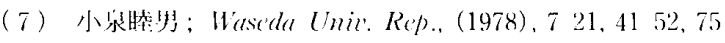
84

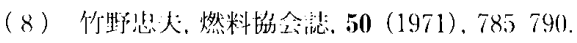

(9) 滕川独, Jpn. Bumer Ins. Rep.. (1995), 16. 